\title{
Unusual cystic lung metastasis
}

\author{
Diaeddin Sagar, ${ }^{1,2}$ Aldrin Adeni ${ }^{3}$
}

${ }^{1}$ Respiratory Department, Doncaster and Bassetlaw Teaching Hospitals NHS Foundation Trust, Doncaster, UK ${ }^{2}$ Respiratory Department, Sheffield Teaching Hospitals, Sheffield, UK

${ }^{3}$ Respiratory Department, Doncaster and Bassetlaw Teaching Hospitals NHS Foundation Trust, Doncaster, UK

Correspondence to Dr Diaeddin Sagar, dia_eddin@yahoo.com

Accepted 29 April 2018

\section{DESCRIPTION}

A 35-year-old woman was recently diagnosed with cervical cancer, confirmed by histology to be squamous cell cancer. A CT of the chest performed as a part of her initial workup did not show any clear evidence of metastasis (figure 1). She underwent chemoradiotherapy with external beam radiotherapy and cisplatin. A positron-emission tomography (PET)-CT of the chest 12 weeks later demonstrated multiple 18F-Fluorodeoxyglucose (FDG)-avid lung nodules suggestive of disease progression (figure 2). She subsequently received palliative therapy with carboplatin and paclitaxel. A follow-up CT chest 4 months later showed multiple bilateral randomly distributed cystic lesions of different sizes (largest measuring $29 \mathrm{~mm}$ ) that were not seen on prior imaging (figure 3). These have been diagnosed as metastatic cystic lung disease.

Cystic lung diseases constitute a different group of conditions where the primary abnormalities in the lungs are cysts. Although lymphangioleiomyomatosis) and Langerhans cell histiocytosis are the most common causes, other conditions, including metastatic lung disease can present in a very similar way. Cavitary lung lesions are well-known findings in metastatic tumours; however, cystic lung metastasis is rare. Metastatic cystic lung lesions have been reported secondary to different types of cancers, including seminoma, Ewing's sarcoma, myxosarcoma, Wilms' tumour, osteogenic sarcoma, angiosarcoma, transitional cell carcinoma, teratocarcinoma and sarcoma of unknown type. ${ }^{1}$ Cystic lung metastasis should be considered in the differential diagnosis when there is a history of squamous cell cancer especially with head and neck primary tumours. ${ }^{1}$ The diagnosis is typically made based on the patient's clinical presentation, the presence of medical problems, CT scan findings and lung biopsy if needed. The diagnosis can be missed in some occasions when the rare causes of cystic lung diseases (like metastasis) are overlooked. Different mechanisms have been implicated in the pathogenesis of lung cysts, these include (1) check-valve

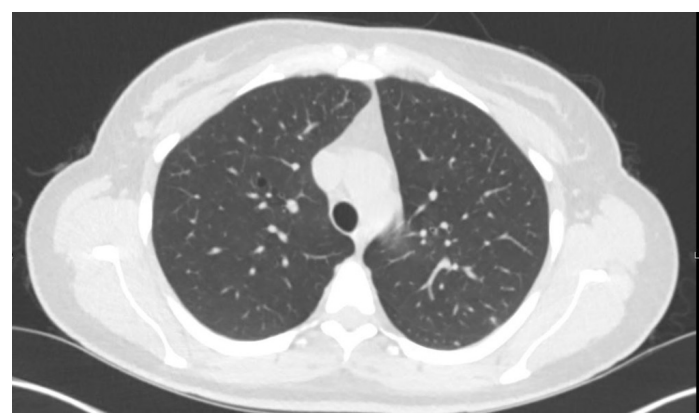

Figure 1 Normal initial CT scan.

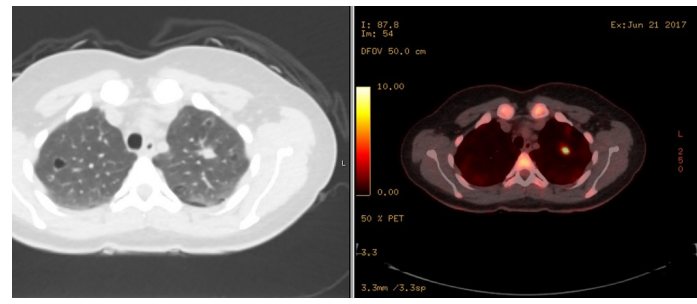

Figure 2 Multiple FDG-avid lung nodules on positron emission tomography-CT.

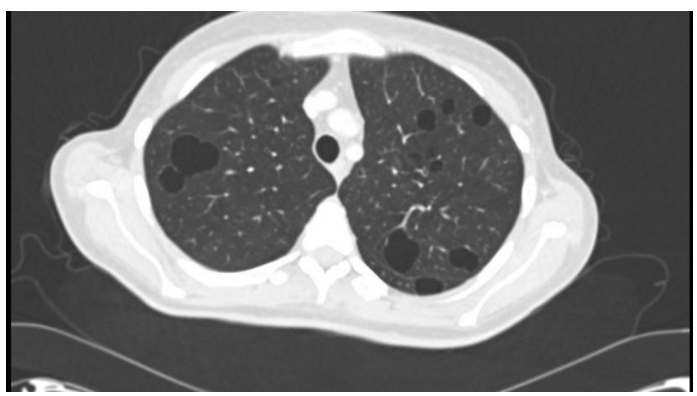

Figure 3 Multiple bilateral randomly distributed lung cysts of different sizes on follow-up CT scan.

\section{Learning points}

- Metastases are one of the rare causes of cystic lung disease, and it should not be overlooked in the differential diagnosis.

- The diagnosis of cystic lung disease requires multidisciplinary approach which involves multiple specialties.

obstruction (allows air flow in one direction) with distal overinflation, (2) infiltration and obstruction of small vessels and capillaries supplying the terminal bronchioles which lead to necrosis and ischaemic dilation of small airways and alveoli, progressing to cyst formation, (3) lung remodelling due to connective tissue degradation and elastolysis by matrix Metalloproteinases and other matrix-degrading enzymes ${ }^{2}$ and (4) excavation of a metastatic nodule $^{3}$ which is the likely mechanism in our case given the prior presence of lung nodules on PET-CT scan.

In our case, although the diagnosis of cystic lung metastasis was not confirmed histologically, the clinical context and the previous positive PET-CT make cystic metastatic lung disease the likely aetiology.

Acknowledgements We Would like to thank Mrs Asmaa Farhat for her valuable writing assistance and express our gratitude to $\mathrm{Dr}$ Ala Eddin Sagar for proof reading the article. 
Contributors DS has contributed by participating in the multidisciplinary team discussion about the patient and her CT and PET scans, collecting the data about the clinical presentation, designing and writing the manuscript. AA has contributed by participating in the multidisciplinary team discussion about the patient and her CT and PET scans, revising the manuscript and supervising it. Both DS and AA have approved this manuscript.

Funding The authors have not declared a specific grant for this research from any funding agency in the public, commercial or not-for-profit sectors.

Competing interests None declared.

Patient consent Obtained.
Provenance and peer review Not commissioned; externally peer reviewed.

(C) BMJ Publishing Group Ltd (unless otherwise stated in the text of the article) 2018. All rights reserved. No commercial use is permitted unless otherwise expressly granted.

\section{REFERENCES}

1 Raoof S, Bondalapati P. Vydyula R, et al. Cystic Lung Diseases. Chest 2016;150:945-65.

2 Gupta N, Vassallo R, Wikenheiser-Brokamp KA, et al. Diffuse Cystic Lung Disease. Part II. Am J Respir Crit Care Med 2015;192:17-29.

3 Ferreira Francisco FA, Soares Souza A, Zanetti G, et al. Multiple cystic lung disease. Eur Respir Rev 2015;24:552-64.

Copyright 2018 BMJ Publishing Group. All rights reserved. For permission to reuse any of this content visit http://group.bmj.com/group/rights-licensing/permissions.

BMJ Case Report Fellows may re-use this article for personal use and teaching without any further permission.

Become a Fellow of BMJ Case Reports today and you can:

- Submit as many cases as you like

- Enjoy fast sympathetic peer review and rapid publication of accepted articles

- Access all the published articles

- Re-use any of the published material for personal use and teaching without further permission

For information on Institutional Fellowships contact consortiasales@bmjgroup.com

Visit casereports.bmj.com for more articles like this and to become a Fellow 